\title{
Improving the Effectiveness of Crude-Oil Hydrocarbon Biodegradation Employing Azotobacter chroococcum as Co-Inoculant
}

\author{
PUJAWATI SURYATMANAPARNADI ${ }^{1 *}$, EDWAN KARDENA², \\ ENNY RATNANINGSIH ${ }^{3} \&$ WISJNUPRAPTO $^{2}$
}

\author{
${ }^{1}$ Soil Science and Land Resources Department, Faculty of Agriculture, Universitas Padjajaran, \\ Jalan Raya Jatinangor Km. 20, Bandung, 40600, Indonesia \\ ${ }^{2}$ Enviromental Engineering Study Programe, ${ }^{3}$ Chemical Study Programe, Institut Teknologi Bandung, \\ Jalan Ganesha No. 10, Bandung 40132, Indonesia
}

\begin{abstract}
Azotobacter chroococcum has a great potential as biosurfactant producing bacteria and was used as co-inoculant to promote the rate of hydrocarbon biodegradation. The rate of hydrocarbon biodegradation were $0.01212,0.01582$, and 0.01766 per day for Acinetobacter sp., Bacillus cereus and the consorsium culture respectively. On the other hand, the rates of biodegradation using Azotobacter as co-inoculant were $0.1472,0.01612$, and $0.02709 \mathrm{~g}$ per day. Azotobacter chroococcum co-inoculant has the capability of increasing biodegradation efficiency of crude oil hydrocarbon. The biodegradation efficiency of petroleum hidrocarbon was increated by $13.4,14.6$, and $14.4 \%$ within the Petrobacter cultures.
\end{abstract}

Key words: Azotobacter chroococcum, biosurfactant, co-inoculant, petroleum hydrocarbon, Petrobacter, rate of biodegradation

The technology for exploiting the ability of og microorganism to degrade crude-oil waste is still considered as one of the most efficient, economical, and environmentally sound methods (Margesin and Schinner 2001). Crude-oil biodegradation often encounters constraints because of its low hydrocarbon biodegradation rate. The rate of biodegradation is restricted by the mass transfer rate from solid phase to liquid phase, while the mass transfer rate is correlated with solubility level of target compound. The low solubility of hydrocarbon, which comprises crude oil, is a problem in degrading the crude oil. Crude oil is always in the size of macrodroplets wich can hamper the process of substrate sorption by oil-degrading bacteria (Van Eyk 1997).

Biosurfactant or bioemulsifier compounds can increase the solubility of crude-oil hydrocarbon. Rhodococcus rhodochrous produces the extracellular compound S-2 (S-2 EPS), i.e. glucose, D-galactose, D-mannose, D-glucoronic acid, and fat. This compound can improve the degradation of aromatic fractions (AF) in crude oil. Biside functioning as a bioemulsifier for AF, the EPS compound can functioned as the carbon source for indigenous crude-oil degrading bacteria that to indigenous bacteria increase the growth rate of

One group of the microorganisms with an extracellular membrane that can act as bioemulsifier is Azotobacter. Azotobacter are nitrogen-fixing, non symbiotic bacteria. For example, A. vinelandii MTCC-2459 can produce an exopolysaccharide compound (EPS) that consists of glucose, rhaminose, galactose, and fucose (Vermani et al. 1997), while A. chroococcum produces extracellular product that can function as bioemulsifier (Wisjnuprapto et al. 2005). With the potential of this genus, A. chroococcum can be utilized as co-inoculant in biodegradation process of crude-oil hydrocarbon. Azotobacter are non-petrophylic bacteria (not

${ }^{*}$ Corresponding author, Phone: +62-22-2504274, Fax: +62-222534115, E-mail: pujawati@biotech.itb.ac.id hydrocarbon-degrading bacteria), but they can produce biosurfactant which in turn can increase the solubility of crude oil.

The objective of this research was to improve the rate and efficiency of crude-oil hydrocarbon biodegradation employing A. chroococcum as a co-inoculant.

\section{MATERIALS AND METHODS}

Azotobacter chroococcum and Petrobacter. The strain A. chroococcum used in this research was obtained from Soil Biology and Biotechnology laboratory, Faculty of Agriculture, Pajajaran University, Bandung. Petrobacter used in this research consisted of Acinetobacter sp. and Bacillus cereus, while Petrobacter consortium consisted of Acinetobacter sp., Bacillus cereus, Enterobacter sp., and Pseudomonas sp. This petrobacter culture was isolated from an area polluted with textile industrial waste in Rancaekek, Bandung, and was known to have the ability of degrading hydrocarbon compounds (Data not shown).

Production media for A. chroococcum and Petrobacter was mineral media $\left(\mathrm{K}_{2} \mathrm{HPO}_{4} 1.5 \mathrm{~g}, \mathrm{KH}_{2} \mathrm{PO}_{4} 0.5 \mathrm{~g}, \mathrm{MgSO}_{4}\right.$ $0.5 \mathrm{~g}$ in 1.01 aquadest) with glucose as carbon source, at $\mathrm{pH}$ 7. Media was sterilized at $121{ }^{\circ} \mathrm{C}$ for 15 minutes. The fermentation for biosurfactant production was conducted at $28{ }^{\circ} \mathrm{C}$ for three days with $100 \mathrm{rpm}$ shaking speed. Biosurfactant used in this research was in the form of a threeday-old A.chroococcum culture, while for the Petrobacter the culture was 36 hours old.

To examine the biodegradation of crude-oil hydrocarbons, we used mineral media assay that contained crude oil as carbon source. Crude oil was obtained from Duri-Riau Field, Pertamina Balongan, Indramayu. The media was sterilized at $121^{\circ} \mathrm{C}$ for 15 minutes.

Biodegradation of Crude-Oil Hydrocarbons. Bacterium A. chroococcum was grown in mineral media at $28{ }^{\circ} \mathrm{C}$ for 
three days with $100 \mathrm{rpm}$ shaking speed. This culture was used as biosurfactant for the degradation of crude-oil hydrocarbons conducted in a 1.0 litre closed culture. The medium was mineral media with $1 \%(\mathrm{v} / \mathrm{v})$ crude oil added as substrate. There were three kinds of Petrobacter cultures used in this research, i.e. Acinetobacter sp., B. cereus, and Petrobacter consortium consisted of Acinetobacter sp., Bacillus cereus, Enterobacter sp., and Pseudomonas sp.

This experiment was designed to be conducted in batch reactor. There were three treatments of Petrobacter culture and another three treatments of Petrobacter culture plus $A$. chroococcum as co-culture. Overall, there were six combinations of treatments each with three replications. The density of the inoculant Petrobacter or A. chroococum used in every closed culture was $2 \%(\mathrm{v} / \mathrm{v})$. Biodegradation process took place for 60 days. For the first 7 days samples were taken at 24-hour intervals. Afterwards, the interval was 7 days. The $\mathrm{pH}$ of the culture condition was adjusted to 7 and then incubated at a $100 \mathrm{rpm}$ shaking speed. Variables observed during biodegradation process were: cell viability, the reduction of total petroleum hydrocarbons $(\mathrm{TPH})$ and residual compounds of biodegradation products. Closed cultures without Petrobacter or A. chroococcum were prepared as controls.

Total Petroleum Hydrocarbons and Determination of its Residual Compounds. The n-hexane extraction method of Iwabuchi (Iwabuchi et al. 2002, modified) was a modified and employed to isolate the residue of Total Petroleum Hydrocarbons from test cultures. Samplings for analysis were taken at 24-hour interval for the first 7 days and there after at 7- day interval.

The Gravimetric method was employed in $\mathrm{TPH}$ biodegradation. First stage TPH was extracted using nhexane solvent. The ratio of sample to $\mathrm{n}$-hexane solvent was $1: 1$, then the solution was then mixed using a vortex mixer at $10 \mathrm{rpm}$. The second stage of the process was separating $\mathrm{TPH}$ by centrifugation at $3500 \mathrm{xg}$ for 10 minutes. This stage produced three layers, at the bottom was the bacterial cells, in the middle was media residue, and at the top was crude oil dissolved in n-hexane. Oil and n-hexane were then poured into a bottle and the extraction process was repeated again until the solution became clear. The third stage was to recover the dissolved TPH through evaporation at $70{ }^{\circ} \mathrm{C}$. After that the weight of the TPH residue was determined.

After crude-oil degradation, hydrocarbon residues were analyzed using GC/MS. Analyses to check the types of compounds contained in the samples before and after processing were conducted at three observation points, i.e. at the beginning of the process, 14 days after starting the process, and at the end of the process. (GC separate the compounds in a gas phase by passing the gas flow through a stationary phase). Retention time in GC indicates the identity of the compounds. MS is a combination of mass analysis used to separate and identify the ions that comprise the components in a complex mixture.

\section{RESULTS}

Crude-Oil Hydrocarbons and the Growth of Tested Bacteria. The biodegradation process by three Petrobacter cultures declined during the exponential growth phase of bacterial cells (Figure 1). The rate of Crude-oil degradation by $B$. cereus decreased sharply during the first 14 days of incubation (Figure 1a), while with the Acinetobacter sp., the decrease happened during the first 7 days (Figure 1b). The reduction of Total Petroleum Hydrocarbons by Petrobacter consortium happened more quickly, also in the first 7 days when the growth was at exponential phase (Figure 1c). After the exponential growth phase, the bacterial population declined, and biodegradation process continued slowly until the end of the incubation period.

Specific Biodegradation Rate and Its Efficiency. The specific TPH biodegradation rate by $B$. cereus, Acinetobacter $\mathrm{sp}$., and Petrobacter consortium increased with the addition of A. chroococcum (Table 1). The same also applied to the
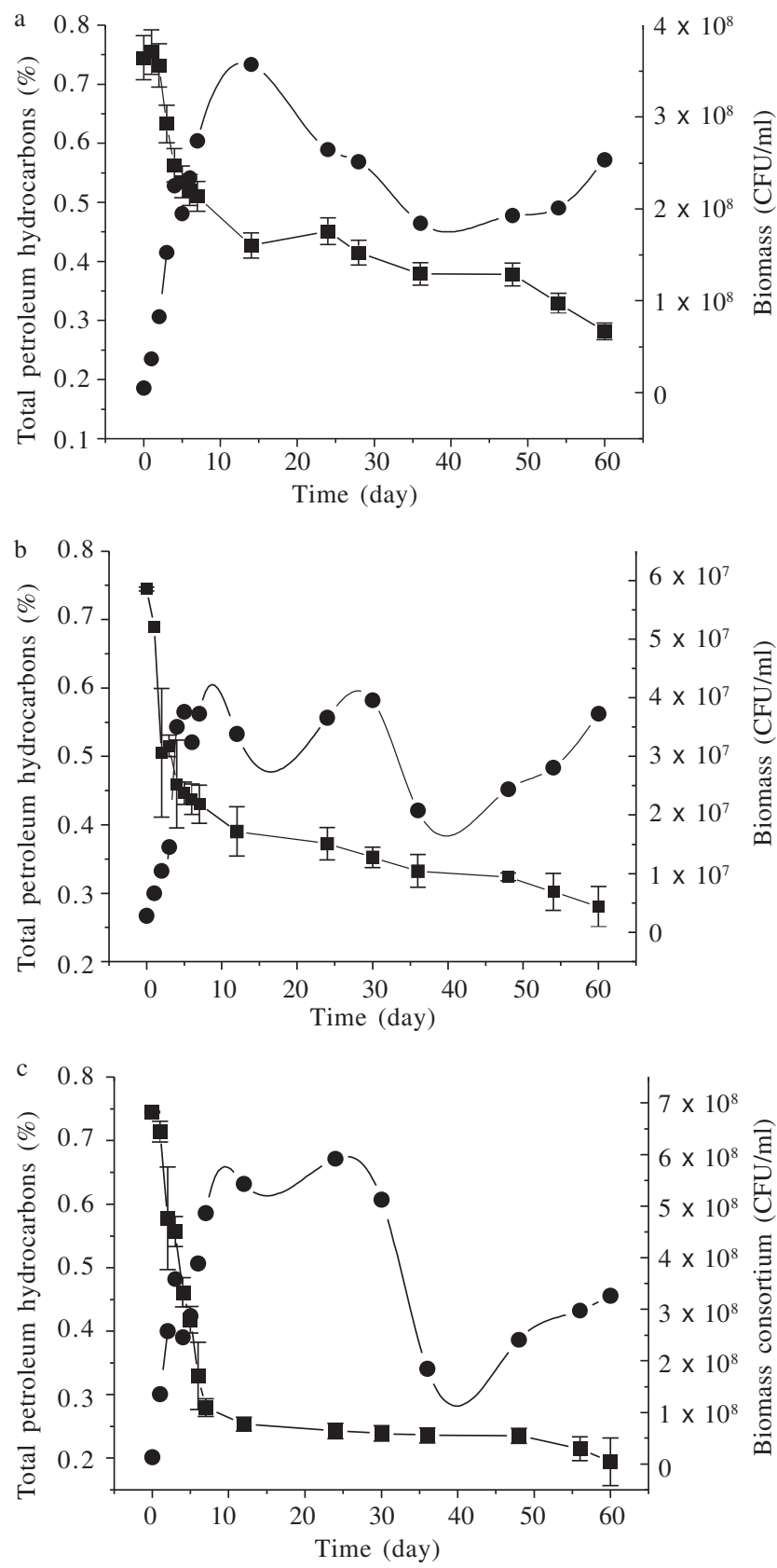

Figure 1 Total petroleum hydrocarbons ( $\mathbf{n}$ ) and bacterial cell biomass ( ) during the growth of Bacillus cereus (a), Acinetobacter sp. (b), and Petrobacter consortium (c) in mineral media plus $1 \%$ crude oil over 60 -day incubation period. 
efficiency of crude-oil hydrocarbon biodegradation by $B$. cereus, Acinetobacter sp., and Petrobacter consortium which was higher compared to control, either with or without the addition of $A$. chroococcum (Tabel 2). The degradation rates were determined from the linear portion of the degradation curves.

The Number of the Hydrocarbon Compounds Residues After Biodegradation Process. The result of he analysis of hydrocarbon residual compounds qualitatively gave proven that $A$. chroococcum was capable encreasing the removal of TPH. It can be showed that the number of the TPH substances detected after biodegradated were qualitatively decreasing (the number of the hydrocarbon substances showed by the number of the peak area in Figure 2, $3 \& 4$ ). The result showed that the crude-oil components comprise 52 hydrocarbon compounds ( $\mathrm{t}-0)$ dominated by aliphatic hydrocarbons, i.e. around $90 \%$ alcane compounds and $10 \%$ aromatic compounds such as benzene and naphthalene. Degradation by B. cereus during the first 14 days still left 37 hydrocarbon compounds as residue (Figure 2a). The culture with $A$. chroococcum as co-inoculant had more effective degradation process; this was shown by 16 hydrocarbon compounds as residue (Figure 2b). The residue from hydrocarbon degradation by Acinetobacter sp. still contained 42 compounds, while the addition of co-inoculant made the process higher with only 15 compound detected as residue (Figure 3a,b). Likewise to hydrocarbon biodegradation by consortium culture, which was higher with the addition of coinoculant $A$. chroococcu. The residue from hydrocarbon degradation by Consortium. still contained 19 compounds, while the addition of co-inoculant made the process higher with only 15 compound detected as residue (Figure 4a,b). That qualitatively data suggest that the removal of the crude oil hydrocarbon was enhanced in the petrobacter culture with the addition of $A$. chroococcum.

\section{DISCUSSION}

In general, the bacteria used in this experiment actively utilized the substrate during logarithmic phase of their growth. This happened because crude oil component as the available hydrocarbons were in the form of aliphatic hydrocarbon groups that could easily be degraded and

Table 1 Specific degradation rate of crude-oil hydrocarbons by three Petrobacter isolates

\begin{tabular}{lc}
\hline Isolate & Biodegradation rate $\left(\mathrm{g} / 1\right.$ day $\left.^{-1}\right)$ \\
\hline B. cereus & 0.01582 \\
B. cereus + A. chroococcum & 0.01612 \\
Acinetobacter sp. & 0.01212 \\
Acinetobacter + A. chroococcum & 0.01472 \\
Consortium & 0.01766 \\
Consortium + A. chroococcum & 0.02709 \\
\hline
\end{tabular}
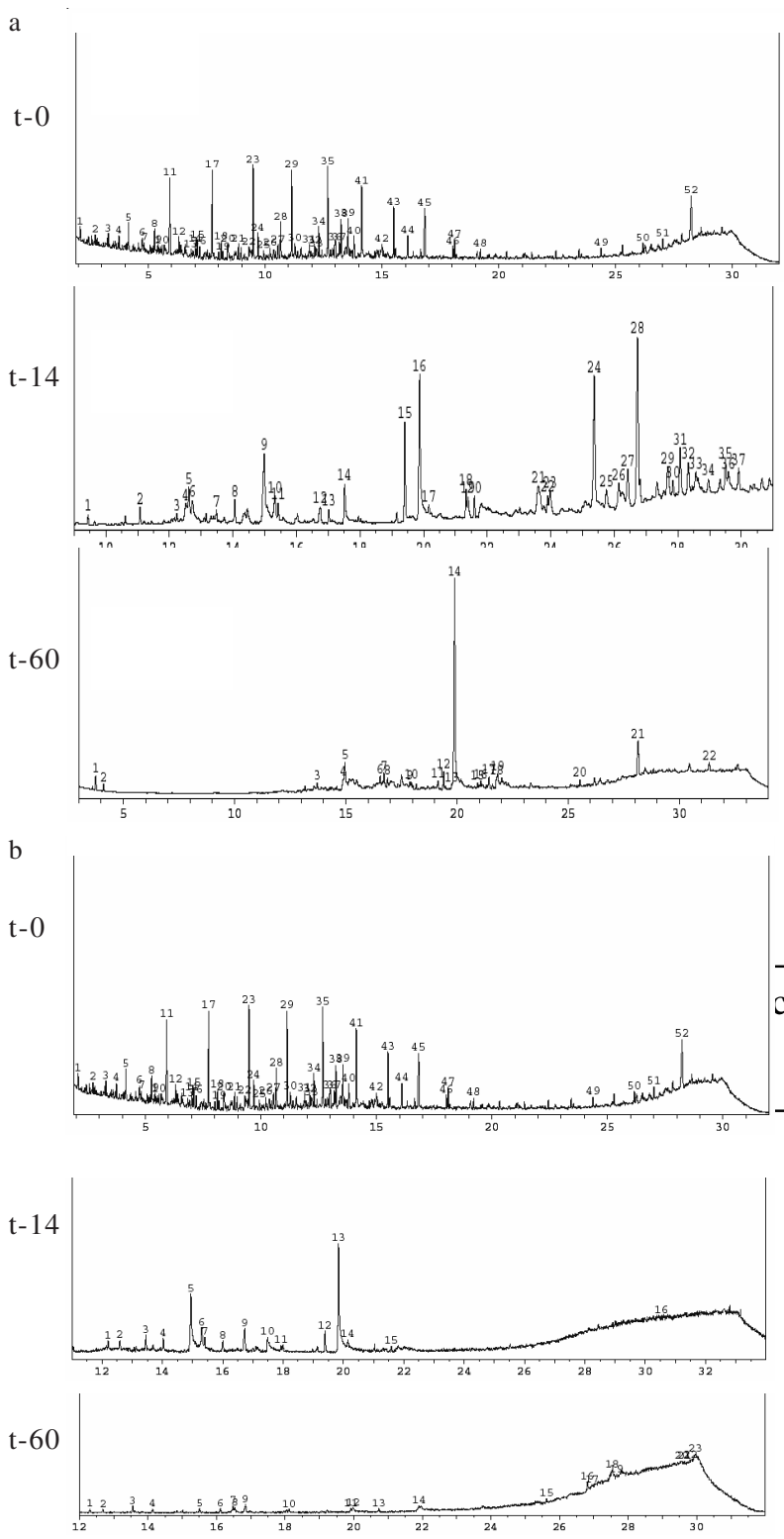

Figure 2 Chromatogram of crude-oil hydrocarbons degradation on different days $(\mathrm{t}=0,14,60)$ in the presence of $B$. cereus alone (a) or with suuplementation of co-inoculant (b).

immediately be used as substrate by the bacteria. The bacterial growth after the exponential phase fluctuated (Figure 1). This caused of the hydrocarbons were transformed into intermediate compounds by Petrobacter. These compounds could be toxic and disturb the growth and viability of Petrobacter's cells. The decline of viability could be interpreted as adaptation phase towards new substrate condition. Other than the presence of intermediate compounds, fluctuations happened because of substrate (carbon source) unavailability, unlike at the beginning of exponential phase when the substrate could be used

Table 2 Efficiency of crude-oil hydrocarbon removal using Petrobacter treatment, with and without the addition of A. chroococcum (coinoculant)

\begin{tabular}{lccr}
\hline Petrobacter isolate & TPH removal efficiency without & \multicolumn{2}{c}{ THP removal efficiency with A. chroococcum } \\
\cline { 2 - 3 } & A. chroococcum $(\%)$ & $(\%)$ & Enhancement TPH removal efficiency $(\%)$ \\
\hline Control (no culture) & $26.51 \pm 1.33$ & $76.67 \pm 1.98$ & $13.16 \pm 0.65$ \\
B. cereus & $62.17 \pm 2.11$ & $70.70 \pm 1.53$ & $14.62 \pm 0.27$ \\
Acinetobacter sp. & $57.26 \pm 1.87$ & $85.57 \pm 2.28$ & $13.44 \pm 0.34$ \\
Consortium & $71.18 \pm 1.56$ & $14.39 \pm 0.07$ & \\
\hline
\end{tabular}



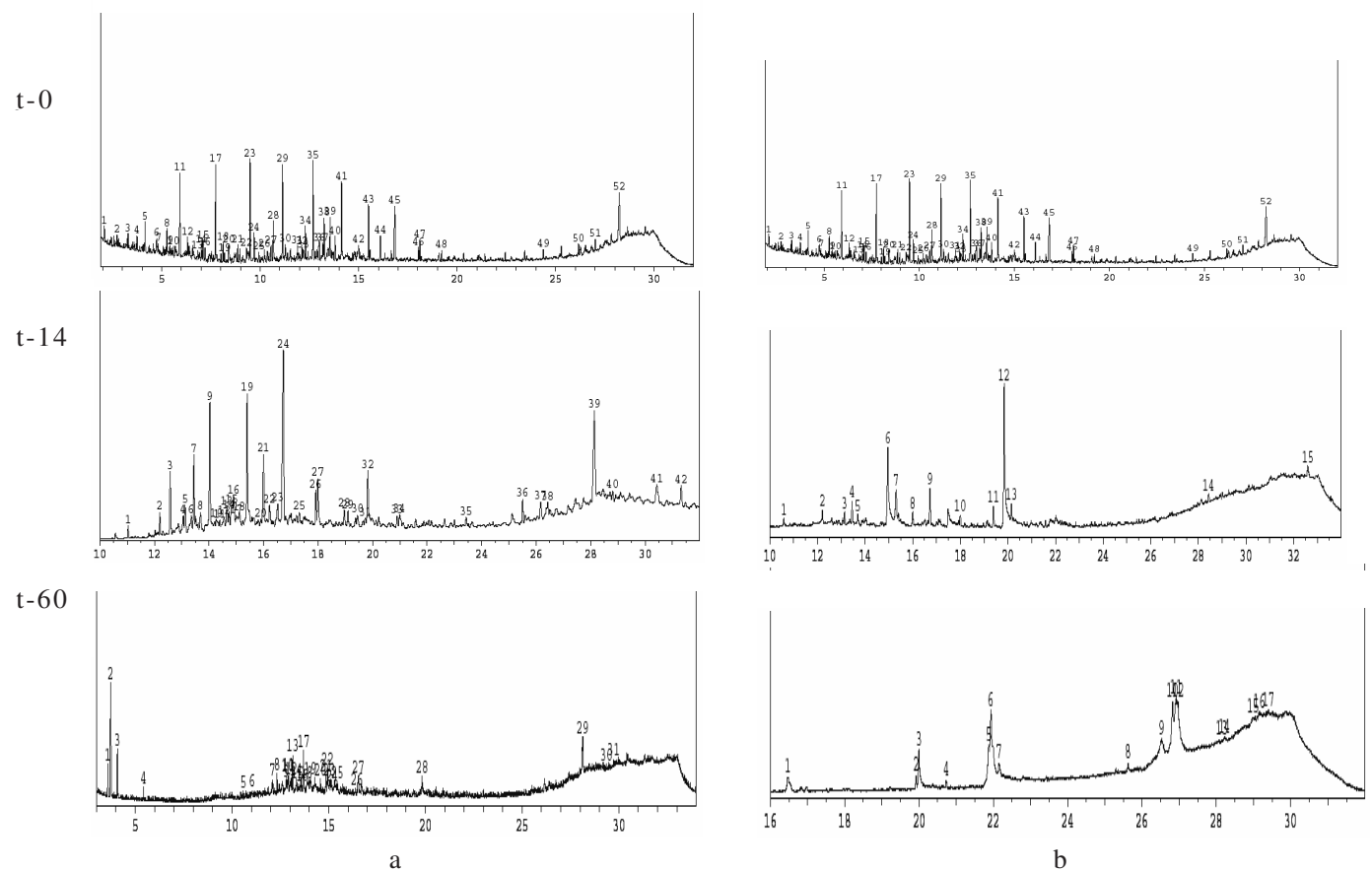

Figure 3 Chromatogram of crude-oil hydrocarbons degradation on different days $(\mathrm{t}=0,14,60)$ in the presence of Acinetobacter sp. alone (a) or with suuplementation of co-inoculant (b).
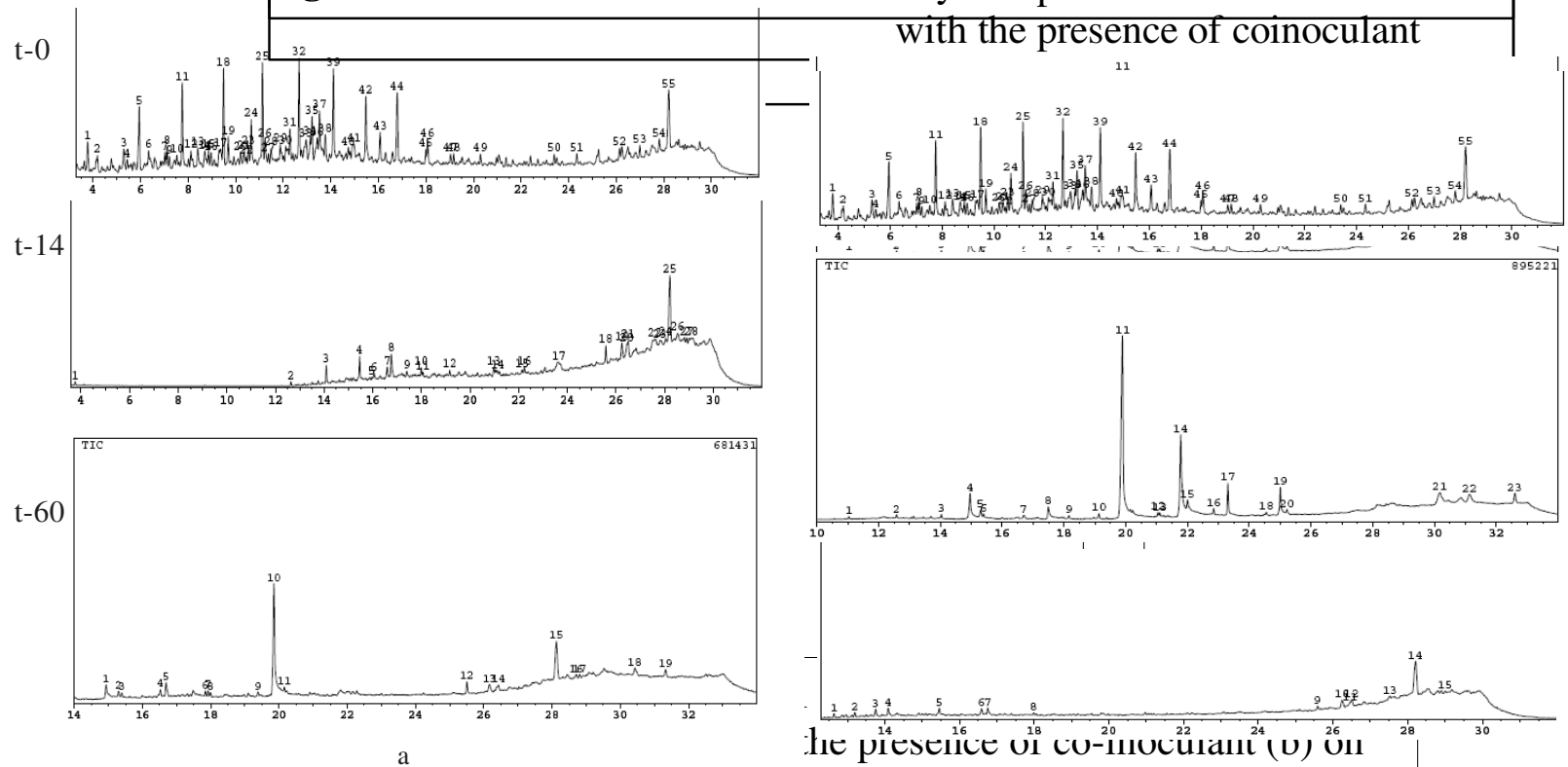

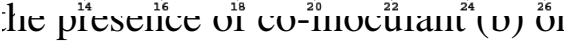

Figure 4 Chromatogram of crude-oil hydrocarbons degradation on amrerent days $(c=0, \sqrt{b}$ ) in the presence consortium alone. (a) or with supplementation of co-inoculant (b).

immediately. Residual compounds as the result of transformation were often resistant to biodegradation process. Besides, aggregation between the available hydrocarbon residual compounds frequently took place. Those compounds were difficult for the bacteria to utilize. This condition, that restricts continued degradation, also correlated with enzymatic activity rate that played a role in further catabolism process of intermediate compounds (Van Eyk 1997).

Bacteria needed time to adapt to, and deal, with the new substrate condition and resistant hydrocarbon residual

\section{hydrocarbons before and after he presence of co-inoculant (b) on}

oon degradation, ubility and slow e to liquid phase. $n$ could increase substrate and hydrocarbon preparation to be immediately used by microorganisms. The enhancement of the TPH degradation rate was closely connected with the bacteria's uptake capacity to utilize the substrate. The higher uptake capacity the bacteria had, the more effective biodegradation process would be. Uptake process is closely related to mass transfer factor of the substrate in liquid phase. In the case of 


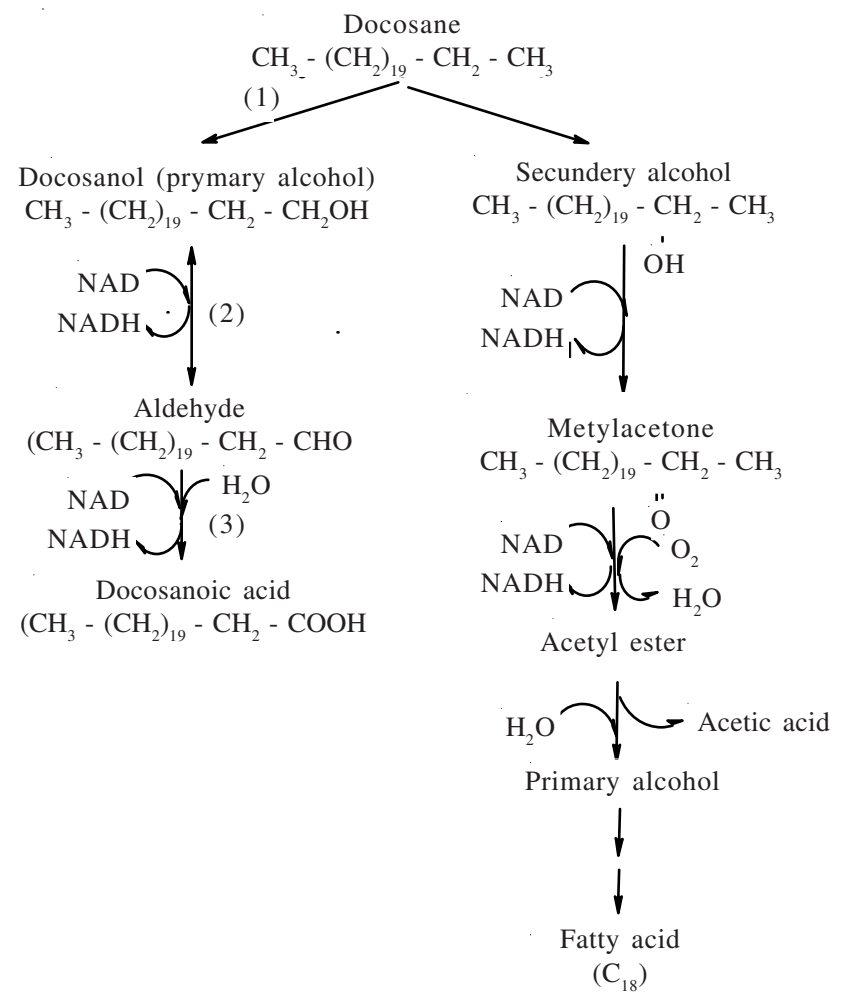

Figure 5 The degradation pathway patern of n-alcane: (1). The forming of docosanol (2), Aldehyde formed from primary alcohol; (3) Aldehyde was changed to the fatty acid (docosanoic acid).

Note: The docosanoic acid and the fatty acids are the predominantly intermediate substances detected after 14 days biodegradation process.

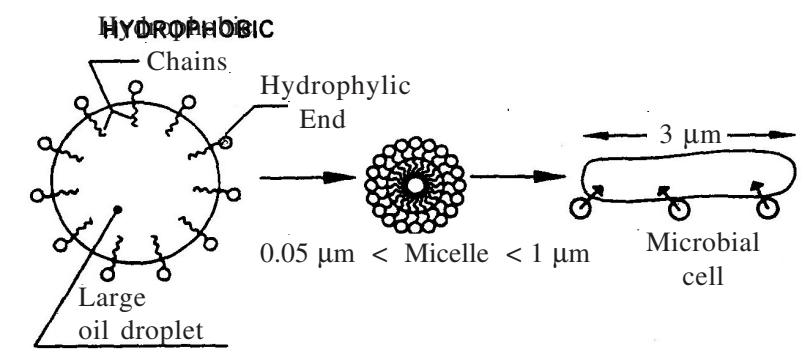

Figure 6 Model mechanism for crude-oil transportation and solubility by biosurfactant (Van Eyk 1997).

crude-oil hydrocarbons, mass transfer factor in liquid phase refers to solubility and dispersion level of oil droplets. Dispersion level is the level when large oil droplets can be emulsified and form oil micelles with maximum size $<1 \mu \mathrm{m}$ which will make substrate absorption by Petrobacter easier.

Co-inoculant A. chroococcum could consistently improve biodegradation rate and the efficiency of crude-oil hydrocarbon biodegradation (Tabel $1 \& 2$ ). This bacterium had been confirmed acting as bioemulsifier that could increase the effectiveness of Petrobacter in the biodegradation process. This could happen because the extracellular substance produced by co-inoculant A.chroococcum could act as bioemulsifier. This bioemulsifier could improve dispersion and solubility of crude-oil hydrocarbons by forming oil micelles measuring $0.5 \mu \mathrm{m}-<$ $1 \mu \mathrm{m}$. These sizes of oil micelles were the suitable and desirable substrate size for Petrobacter cell to absorb them immediately so that hydrocarbon degradation process could be more effective. This was proven by the resistance and low solubility in hydrocarbon compound degradation process which happened after the first week. The Hydrocarbon degradation process was improved with the presence of A. chroococcum as co-inoculant, it could increase the solubility of residual hydrocarbon compounds, which were difficult to dissolve and degrade. Co-inoculant A. chroococcum, a biosurfactant producing bacteria, could function as a bioemulsifier reservoir in an environment containing hydrocarbons. The biosurfactant mechanism in crude oil biodegradation is shown in Figure 6. The $A$. chroococcum functioned as biosurfactant reservoir by forming oil micelles from large oil droplets. The outer layers of oil micelles were biosurfactant that had hydrophylic sequence, while the inner layer had hydrophobic sequence, these oil micelles acted as transport vehicles to form aggregates and performed crude-oil absorption process through bacterial cell wall (Van Eyk 1997). The bioemulsifier produced by A. chroococcum consisted of various fatty acid compounds acting as bioemulsifier that had amphiphatic characteristics (Suryatmana et al. 2006). These organic compound groups acted as Ligan Taxi System (transport vehicles) in the uptake process of hydrocarbons by Petrobacter. Therefore, Petrobacter could utilize the substrate more effectively.

The effect of biosurfactant on hydrocarbon degradation was based on increased hydrocarbon solubility and dispersion, and a change of the affinity between bacterial cell and hydrocarbon through induction that resulted in - 'ydrophobicity of cell surface (Zhang \& Miller 1995). With that mechanism, the rate and effectiveness of hydrocarbon adhesion was increased. The adhesion process was a very vital starting process in substrate uptake.

Consortium isolate showed the most effective characteristics in crude-oil hydrocarbon degradation. This was indicated by the highest biodegradation rate and efficiency. Likewise, Petrobacter consortium (more than one bacterial species) had higher probability of metabolic diversity compared to one bacterial species. In the consortium culture, combined performance in utilizing carbon source could happen between consortium members. A consortium of Bacillus cereus, Acinetobacter sp., Enterobacter sp., and Pseudomonas sp. was a mix live that could positively interact and cooperate in using diverse substrate sources contained in crude oil.

Every Petrobacter isolate had a different level of ability in degrading aliphatic hydrocarbons contained in crude oil from Duri, like B. cereus and Acinetobacter sp. wich were able to degrade aliphatic hydrocarbon $\mathrm{C} 7$ to $\mathrm{C} 18$, while the consortium was able to degrade aliphatic hydrocarbons $\mathrm{C} 7$ to $\mathrm{C} 22$ (Figure 5). With those various metabolic abilities, the consortium culture prove more effective in TPH degradation activity compared to a single culture.

The result was indicated that intermediate compounds formed in the degradation process were in the form of various organic compounds dominated by fatty acids. The fatty acids might be an intermediate substances formed in alcane hydrocarbon degradation process by all the petrobacter used. The hypothetic of the alcane (docosane) biodegradation pathway by the consortium was showed in 
Figure 5. That hypothetic pathway was constructed based on the predominantly substances detected and was correlated by the aliphatic pathway of the Hofrichter's patern. The process from docosane (aliphatic hydrocarbon) may involved oxygenase enzyme systems. Alcane monoterminal oxidation pathway involves alcohol dehydrogenase formed docosanol. The alcohol dehydrogenase is intracellular enzyme which works together with electron carrier systems. Following aldehyde compounds (docosanal) formed from docosanol, that involve aldehyde dehydrogenase. The reaction process is followed by fatty acids (docosanoic acid) formation that requires $\mathrm{NAD}^{+}$. The next process is where fatty acid assembled in cellular lipid and plays a role in provide energy through the $\beta$-oxidation pathway. The activation of fatty acid and coA results in the release of acetyl-coA, forming shorter fatty acids than alcane from original compounds, followed by the release of carbon dioxide. The acetyl coA then enters anabolic pathways to form new cells. In subterminal pathway reactions, alcane is changed into secondary alcohol before changed again into primary alcohol, and then transformed into fatty acid.

\section{ACKNOWLEDGMENTS}

We thank Ministry of Research and Technology of Republic of Indonesia, for supporting this research through Riset Unggulan Terpadu XI (RUT XI) 2004-2006; Reginawanti Hindersyah, Dept. of Soil Science, Faculty of Agriculture, Padjadjaran University (UNPAD), for permission to use her isolate (Azotobacter chroococcum) in this research; Made
Rhena Yasa (Head of Development Laboratory), PT PERTAMINA Indonesia, Balongan-Indramayu Production Unit, for the assistance given during this research.

\section{REFERENCES}

Fritsche W, Hofrichter M. 2000. Aerobic Degradation by Microorganisms. In: Rehm HJ, Reed G (ed). Biotechnology. $2^{\text {nd }}$ ed. Weinheim: Wiley-VCH.

Iwabuchi N et al. 2002. Extracellular polysaccharides of Rhodococus rhodochrous S-2 stimulate the degradation of aromatic components in crude oil by indigenous marine bacteria. Appl Environ Microbiol 68:2337.

Margesin S. 2001. Bioremediation (natural attenuation and biostimulation) of diese-oil-contaminated soil in an alpine glacier skiing area. Appl Environ Microbiol 67:3127-3133.

Suryatmana P, Kardena E, Ratnaningsih E, Wisjnuprapto. 2006. [The characterization of biosurfactant from Azotobacter chroococcum]. [In Indonesian]. J Mikrobiol Indones 11:30-34.

Van Eyk J. 1997. Petrolium Bioventing. Roterdam-Brookfield: A.A.Balkema.

Vermani MV, Kelkar SM, Kramat MY. 1997. Studies in polysaccharide production and growth of Azotobacter vielandii MTCC 2459, a plant rhizosfir isolate. Soc Appl Bacteriol Lett Appl Microbiol 24:379-383.

Wisjnuprapto, Kardena E, Parnadi PS, Gladys S, Kristanti N. 2005. Bioremediation of petroleum oil contaminated soils. p 31-34. Proceedings of the COE Joint Symposium on Environmental Engineering Between Hokkaido University, Chungbuk National University and Bandung Institut of Technology. Sapporo-Japan, 2-4 Feb 2005.

Zang, Miller. 1995. Effect rhamnolipid (biosurfactant) structure on solubilization and biodegradation of n-alkanes. Appl Environ Microbiol 61:2247-2251. 